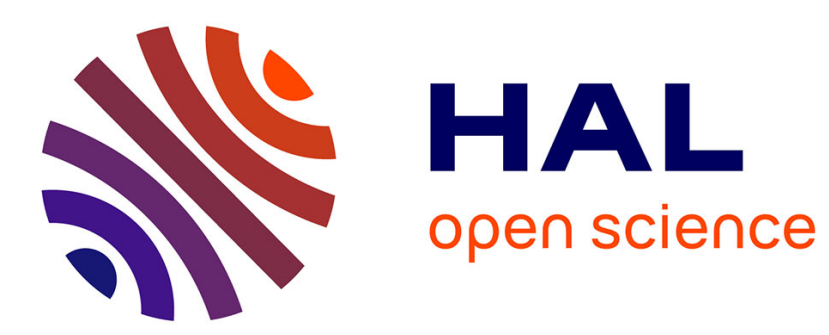

\title{
Comparison of the leaching behaviour of two maize herbicides: atrazine and sulcotrione
}

Richard Cherrier, Arnaud Boivin, Corinne Perrin-Ganier, Michel Schiavon

\section{To cite this version:}

Richard Cherrier, Arnaud Boivin, Corinne Perrin-Ganier, Michel Schiavon. Comparison of the leaching behaviour of two maize herbicides: atrazine and sulcotrione. Agronomy for Sustainable Development, 2005, 25 (2), pp.293-299. hal-00886273

\section{HAL Id: hal-00886273 https://hal.science/hal-00886273}

Submitted on 1 Jan 2005

HAL is a multi-disciplinary open access archive for the deposit and dissemination of scientific research documents, whether they are published or not. The documents may come from teaching and research institutions in France or abroad, or from public or private research centers.
L'archive ouverte pluridisciplinaire HAL, est destinée au dépôt et à la diffusion de documents scientifiques de niveau recherche, publiés ou non, émanant des établissements d'enseignement et de recherche français ou étrangers, des laboratoires publics ou privés. 


\title{
Comparison of the leaching behaviour of two maize herbicides: atrazine and sulcotrione
}

\author{
Richard CHERRIER*, Arnaud BOIVIn, Corinne PERRIN-GANIER, Michel SCHIAVON \\ Laboratoire Sols et Environnement, INPL-ENSAIA/INRA, UMR 1120, 2 avenue de la Forêt de Haye, BP 172, 54505 Vandœuvre-lès-Nancy, France
}

(Accepted 13 October 2004)

\begin{abstract}
In a soil column experiment under outdoor conditions, we monitored the fate of ${ }^{14} \mathrm{C}$-ring-labelled sulcotrione and atrazine in water percolates and in the ploughed horizon of a sandy-silty soil. The application rates were 1000 and $450 \mathrm{~g} \cdot \mathrm{ha}^{-1}$, respectively, for atrazine and sulcotrione. Two months after treatment, the cumulative amounts of herbicide residues leached from the soil were $14.5 \%$ and $7 \%$ of the applied radioactivity for sulcotrione and atrazine, respectively. The maximum percolate concentrations for each herbicide were observed during the first month following application; $120 \mu \mathrm{g} \cdot \mathrm{L}^{-1}$ and $95 \mu \mathrm{g} \cdot \mathrm{L}^{-1}$ for sulcotrione and atrazine, respectively. After 2 weeks, $78 \%$ of the sulcotrione and atrazine was extractable from the soil, whereas after two months only $10 \%$ and $4 \%$, respectively, could be extracted. The maximum sulcotrione and atrazine contents in the first ten centimetres of soil were identical. For both molecules, the content of non-extractable residues was low, being around $15 \%$. The sulcotrione seems to be a more mobile product than the atrazine. Even if much smaller leachate concentrations would be expected to impact groundwater than those found in this study, the classification of the molecules would stay the same.
\end{abstract}

soil columns / pesticide fate / bound residues / soil and water pollution

\section{INTRODUCTION}

Atrazine (6-chloro- $\mathrm{N}^{2}$-ethyl- $\mathrm{N}^{4}$-isopropyl-1,3,5-triazine2,4diamine) is frequently recovered in tile-drain water (Moore et al., 2001; Tan et al., 2002), in surface water (Garmouna et al., 1998; Blanchoud et al., 2002) and in groundwater (Wehtze et al., 1983; Davoli et al., 1987). Recommendations in terms of treatment for maize mostly correspond to a diversification in the products used. Amongst these, sulcotrione (2-[2-chloro4(methylsulfonyl)benzoyl]-1,3-cyclohexanedione) has already proved its agricultural efficiency (Beraud et al., 1992) and is widely applied, even if its behaviour in the environment remains poorly understood (Fischer and Siebers, 1997).

Atrazine was a herbicide applied at the rate of $1000 \mathrm{~g} \cdot \mathrm{ha}^{-1}$ for pre- and post-emergence control of annual broad-leaved weeds and annual grasses in maize. Atrazine was also used in combination with many other herbicides. Its use has been prohibited in France since June 2003. Its water solubility is $33 \mathrm{mg} \cdot \mathrm{L}^{-1}$ at $25^{\circ} \mathrm{C}$. The major role of organic matter in retention of atrazine has been underlined on several occasions (Bailey et al., 1968; Calvet et al., 1980; Dousset et al., 1994). The retention of atrazine is more intense when the organic matter is humified (Calvet, 1988; Dousset, 1994). It was considered relatively recalcitrant in soils, although microbial degradation has always been recognised as the principal mechanism of atrazine dissipation in soils (Kaufman and Kearney, 1970). Field DT 50 was between 6 and 77 days, the higher values being from cold or dry conditions. Complete and rapid mineralisation of the ${ }^{14} \mathrm{C}$ labelled $s$-triazine ring, both by soil populations and by bacterial isolates, is now commonly observed (Assaf and Turco, 1994; Barriuso and Houot, 1996). Major metabolites under all conditions are desethylatrazine, deisopropylatrazine and hydroxyatrazine (Houot et al., 2000).

Sulcotrione is a herbicide applied at the rate of $450 \mathrm{~g} \cdot \mathrm{ha}^{-1}$ at maize post-emergence at the 5 to 6 leaf development stage (Beraud et al., 1992). It is absorbed by the leaves and also by the roots. Its water solubility is $165 \mathrm{mg} \cdot \mathrm{L}^{-1}$ at $25{ }^{\circ} \mathrm{C}$. Wilson and Foy (1992) showed that sulcotrione adsorption is correlated to the soil organic matter content. According to Rouchaud et al. (1996, 1998a, b) and Baer (1996) and Cherrier et al. (2004), sulcotrione is persistent for a short time but mobile. Its degradation produces three metabolites, of which CMBA (2-chloro4(methylsulfonyl)benzoïc acid) is the main metabolite with no herbicide activity.

Because of its wide use and its physical and chemical characteristics, the objective of our study was to compare sulcotrione and atrazine leaching throughout soil columns under outdoor climatic conditions. For this purpose, we measured atrazine and sulcotrione residues in the percolates of soil columns and we quantified the amount of residues, including their extractability from the soil, during the leaching experiment.

\footnotetext{
* Corresponding author: richard.cherrier@ensaia.inpl-nancy.fr
} 


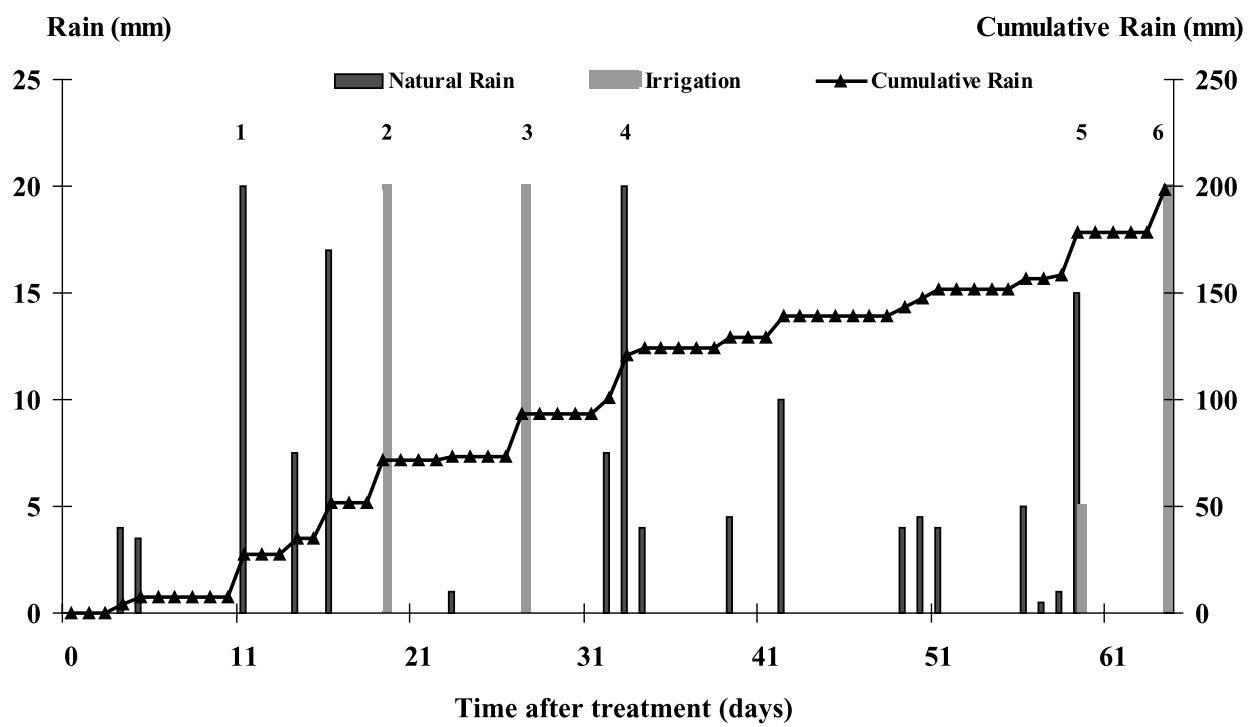

Figure 1. Rainfall and irrigation at an experimental ENSAIA site in Nancy (Lorraine, France) during the June/August 2002 monitoring periods. Leachate collection times are numbered from 1 to 6 .

\section{MATERIALS AND METHODS}

\subsection{Soil columns}

Ten columns were taken from the topsoil of an agricultural field in Lorraine (northeast France; Lambert 2 co-ordinates are $\mathrm{X}=867.325, \mathrm{Y}=2.381 .250, \mathrm{Z}=435)$. The soil presented $\mathrm{a}$ sandy loam texture (USDA triangle) ( $\mathrm{pH} 6.5$ and OC $0.72 \%$ ), and is a dystric cambisol (FAO classification) or a Brunisol Oligo Saturé (French classification).

The columns were collected in PVC tubes, $30 \mathrm{~cm}$ long with an internal diameter of $9.8 \mathrm{~cm}$ and a bevelled base to facilitate soil penetration. Each column was composed of $28 \mathrm{~cm}$ of soil, corresponding to $5 \mathrm{~cm}$ of the undisturbed underground $\mathrm{B}$ horizon and $23 \mathrm{~cm}$ of the reconstituted ploughing horizon. For the collection of the B horizon, firstly the ploughing horizon was removed and the pipe was slowly pushed down into the soil with a hammer, the soil around the pipe being progressively removed to reduce compaction inside the column. Secondly, $23 \mathrm{~cm}$ of the ploughing horizon was added to the surface. The soil columns were then attached to a funnel in order to collect the percolating water in a bottle. The columns were then placed in a rack of an experimental ENSAIA site in Nancy (Lorraine, France), $45 \mathrm{~km}$ from the field from which they were sampled. After setting the 10 columns, the rack was filled with sand to simulate field conditions and avoiding thermic effects. Throughout the experiment, the columns remained free from vegetation, because of their small diameter.

\subsection{Treatment}

An isotopic dilution in methanol of cold and radioactive atrazine or sulcotrione, labelled with ${ }^{14} \mathrm{C}$ on the s-triazinic ring for atrazine and on the benzene ring for sulcotrione, was carried out on June 10, 2002. This isotopic dilution was performed in order to apply the equivalent of $1000 \mathrm{~g} \cdot \mathrm{ha}^{-1}$ of atrazine and
$450 \mathrm{~g} \cdot \mathrm{ha}^{-1}$ of sulcotrione, which are the usual application rates on maize. Eight millilitres of either atrazine or sulcotrione methanol treatment solution were dripped with a pipette onto the soil surface of each column. For atrazine, this represents $0.75 \mathrm{mg}$ and $0.56 \mathrm{MBq}$ (specific radioactivity of the isotopic dilution solution: $0.74 \mathrm{MBq} \cdot \mathrm{mg}^{-1} ; 95 \%$ purity, Izotop) and for sulcotrione, $0.34 \mathrm{mg}$ and $1.02 \mathrm{MBq}$ (specific radioactivity of the isotopic dilution solution: $3.02 \mathrm{MBq} \cdot \mathrm{mg}^{-1}, 90 \%$ purity, Izotop) per column.

\subsection{Leachate collection}

All the leachates were collected in glass sampling bottles $(2.5 \mathrm{~L})$ after natural rain and/or artificial irrigation, because of a low pluviometry, at 12, 20, 28, 34, 60 and 65 days after treatment. At each date, the artificial water was provided the day before the sampling. Leachates were harvested after a complete stop of the water flow. The sum of natural rain and artificial irrigation corresponded to $20 \mathrm{~mm}$ of water (Fig. 1). Irrigation water was provided at a rate of $30 \mathrm{~mL}$ of distilled water per hour. The cumulated percolates between two sampling dates were harvested individually to determine the leachate volume and the radioactivity contained. The volume of the water collected was measured with a graduated test tube. The ${ }^{14} \mathrm{C}$ radioactivity of the samples was determined by $\beta$ counting with liquid scintillation counting (LSC) in a Packard Tri-Carb 1900 CA. 1-mL subsamples of each percolate were taken and $10 \mathrm{~mL}$ of Ultima Gold Scintillator (Packard) were added.

\subsection{Residues in soil}

\subsubsection{Extractable ${ }^{14}$ C residues}

Columns were removed at $0,15,30,45$ and 65 days after treatment. The ${ }^{14} \mathrm{C}$-labelled residues were extracted from soil 


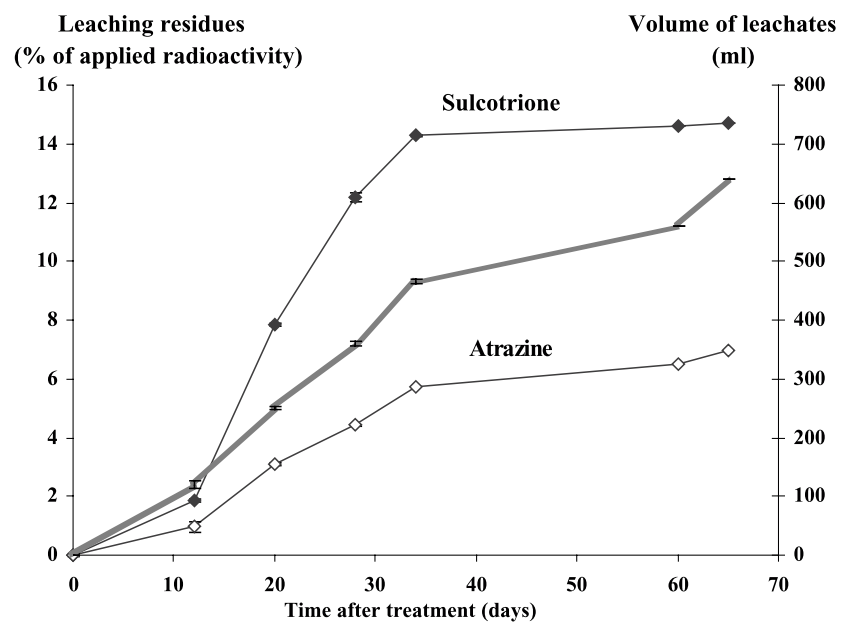

Figure 2. Cumulative exportations of sulcotrione and atrazine residues in the leachates during the two months of the soil column experiment, and cumulative volumes of leachates produced during the experiment, average of the replicates. For each molecule: at day 12 [4 replicates]; at days 20 and 28 [ 3 replicates]; at day 34 [2 replicates] and at days 60 and 65 [1 replicate]. The standard deviation bars are not shown, as they are smaller than the symbols.

(50 g samples) at depths of 0-5, 5-10, 10-15, 15-23 and 23$28 \mathrm{~cm}$ in the following way. The soil layer sample was transferred into a $250-\mathrm{mL}$ PTFE centrifuge flask. The soil was agitated on a rotary shaker for $2 \mathrm{~h}$ with, first, $100 \mathrm{~mL}$ of water with $\mathrm{CaCl}_{2}$ $0.01 \mathrm{M}$, and for the other extractions (two or three extractions according to the date of sampling) $100 \mathrm{~mL}$ of acetonitrile / hydrochloric acid 0.1 M (90/10) (v/v) for sulcotrione samples or $100 \mathrm{~mL}$ of methanol for atrazine samples. In each case, the soil was centrifuged at $4642 \mathrm{~g}, 20^{\circ} \mathrm{C}$, for $25 \mathrm{~min}$ (Avanti J-25, Beckman). The amount of extractable ${ }^{14} \mathrm{C}$ residue in the supernatant was evaluated by liquid scintillation counting. The extractions were stopped when the activity detected in the supernatant corresponded to twice the background noise, i.e. 1.6 Bq. The successive extractions from each sample were then mixed, residues in the supernatant solution were filtrated at $0.2 \mu \mathrm{m}$ with a Sartorius filter (Minisart SRP15) and concentrated by evaporation of the solvent until dry with a rotovapor (Heidolph 94200) at $35^{\circ} \mathrm{C}$. The residues were then dissolved in $2 \times 0.5 \mathrm{~mL}$ of acetonitrile / chloridric acid $0.1 \mathrm{M}(90 / 10)(\mathrm{v} / \mathrm{v})$ for sulcotrione and $2 \times 0.5 \mathrm{~mL}$ of HPLC methanol for atrazine.

Residual herbicides in the soil extracts were determined by HPLC on a Varian chromatograph equipped with a C18 Merck LichroCart $250-4$ column $(25 \mathrm{~cm})$, a diode array detector (Varian 330) and a $\beta$ detector (Flo-one Packard). For the analyses, we used the following operating conditions: wavelength $239 \mathrm{~nm}$ for atrazine and $282 \mathrm{~nm}$ for sulcotrione, injection volume $80 \mu \mathrm{L}$, analysis time $20 \mathrm{~min}$, flow rate $0.8 \mathrm{ml} \cdot \mathrm{mn}^{-1}$ and elution with acetonitrile / water acidified at $\mathrm{pH} 3$ with $\mathrm{H}_{3} \mathrm{PO}_{3}$ $\mathrm{M}(50 / 50)(\mathrm{v} / \mathrm{v})$. Qualitative peak quantification was performed by a $\beta$ radioactivity detector in the following conditions: Scintillator Ultima Flo (Packard), flow rate $1.2 \mathrm{~mL} \cdot \mathrm{mn}^{-1}$ and counting cell volume $500 \mu \mathrm{L}$. The limit of atrazine and sulcotrione detection under these conditions was $2 \mathrm{~Bq}$.

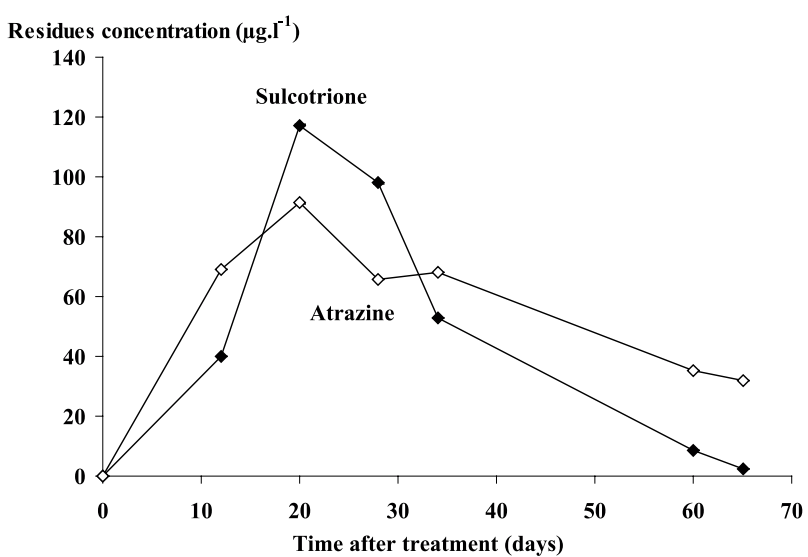

Figure 3. Evolution of sulcotrione and atrazine concentration in soil column water percolates $\left(\mu \mathrm{g} \cdot \mathrm{L}^{-1}\right)$. Error bars when not visible are masked by the symbols. For each molecule: at day 12 [4 replicates]; at days 20 and 28 [3 replicates]; at day 34 [2 replicates] and at days 60 and 65 [ 1 replicate].

\subsubsection{Non-extractable ${ }^{14} \mathrm{C}$ residues}

After exhaustive extractions, all the soil samples were airdried and ground. The non-extractable ${ }^{14} \mathrm{C}$ residues were evaluated in duplicate by combustion in the following way. An aliquot of $0.3 \mathrm{~g}$ of soil was mixed with $0.1 \mathrm{~g}$ of cellulose powder to improve combustion. The sample was burnt at $900{ }^{\circ} \mathrm{C}$ with a 307 Packard Oxidizer. The ${ }^{14} \mathrm{CO}_{2}$ evolved was trapped with $10 \mathrm{~mL}$ Carbo-Sorb E (Packard) and the radioactivity was evaluated by liquid scintillation counting after the addition of $10 \mathrm{~mL}$ of Permafluor scintillator (Packard).

\section{RESULTS AND DISCUSSION}

\subsection{Distribution of the pesticide residues in the leachates}

\subsubsection{Leaching dynamics of the residues}

After the first input of water on a dry soil, equivalent to $20 \mathrm{~mm}$ of rain, at day 11 after treatment, $2 \%$ of sulcotrione was leached versus $1 \%$ for atrazine (Fig. 2). The following three rainfall inputs (equivalent to $20 \mathrm{~mm}$ of water for each) at days 19-27-33 after treatment (Fig. 1) were more efficient at leaching than the initial water input, with $12 \%$ of the product applied, for sulcotrione, and 5\% for atrazine in 22 days. The next rainfalls, 59 and 64 days after treatment, induced limited leaching: $0.5 \%$ and $1 \%$ of sulcotrione and atrazine, respectively. Finally, $14.5 \%$ and $7 \%$ of the applied sulcotrione and atrazine were, respectively, leached during the 2 months of the experiment.

\subsubsection{Residue contents in the percolates}

The high availability of sulcotrione for leaching was confirmed by the maximum concentrations of the residues measured as $120 \mu \mathrm{g} \cdot \mathrm{L}^{-1}\left( \pm 0.7 \mu \mathrm{g} \cdot \mathrm{L}^{-1}\right)$ (input of $450 \mathrm{~g} \cdot \mathrm{ha}^{-1}$ ) versus $95 \mu \mathrm{g} \cdot \mathrm{L}^{-1}\left( \pm 1.4 \mu \mathrm{g} \cdot \mathrm{L}^{-1}\right)$ (input of $1000 \mathrm{~g} \cdot \mathrm{ha}^{-\mathrm{P}}$ ) for atrazine (Fig. 3). Maximum concentrations were observed for both 
Table I. Cumulative values of $\%$ of extractable residues of sulcotrione and atrazine by water and solvent during the two months of experiment in the whole columns.

\begin{tabular}{ccc}
\hline Time days & $\begin{array}{c}\text { \% extractable residues } \\
\text { of sulcotrione }\end{array}$ & $\begin{array}{c}\text { \% extractable residues } \\
\text { of atrazine }\end{array}$ \\
\hline 0 & 100 & 98 \\
15 & 77 & 79 \\
30 & 38 & 16 \\
45 & 8 & 9 \\
65 & 10 & 4 \\
\hline
\end{tabular}

products during the first month of experimentation and decreased rapidly afterwards. During the second month of the experiment, the concentrations of atrazine in percolates were higher than those of sulcotrione.

\subsection{Distribution of the pesticide residues in the soils}

\subsubsection{Distribution profile of soil extractable residues and composition}

On the day of treatment, almost all the residues were extracted, $100 \%$ for sulcotrione and $98 \%$ for atrazine (Tab. I).
After 15 days of experimentation, $77 \%$ of sulcotrione residues and $79 \%$ of atrazine residues could be extracted by water and solvent. After 30 days of experimentation, $38 \%$ and $16 \%$, respectively, of sulcotrione and atrazine residues could be extracted. It would seem that mineralisation and the formation of non-extractable residues did contribute to the extractable residues reduction. At the end of the 65-day experiment, the extractable residue content remained low, close to $10 \%$ and $4 \%$, respectively, for sulcotrione and atrazine residues.

The maximum sulcotrione content was always similar to that of atrazine in the surface layer $(0-5 \mathrm{~cm})$ of the soil. At day 15, it represented, respectively, $59 \%$ and $68 \%$ of the product applied on the surface (Fig. 4a, b). However, we were able to observe a greater atrazine residue redistribution in the soil profile than that of sulcotrione at the end of the experiment.

In each case, 15 days after treatment, a degradation of the product was visible, into two metabolites for sulcotrione ((2chloro-4(methylsulfonyl)benzoïc acid) = CMBA and metabolite 2) and just one for atrazine (desethylatrazine = DEA) (Tab. II). The transformations of sulcotrione into metabolites were more intense, in the surface layer, where the extractable residues were composed of $18 \%$ of sulcotrione versus $85 \%$ for atrazine. Thirty days after treatment, sulcotrione was weakly present in the extractable residues, at only $7 \%$. At the same time, atrazine composed $50 \%$ of the extractable residues and

a.

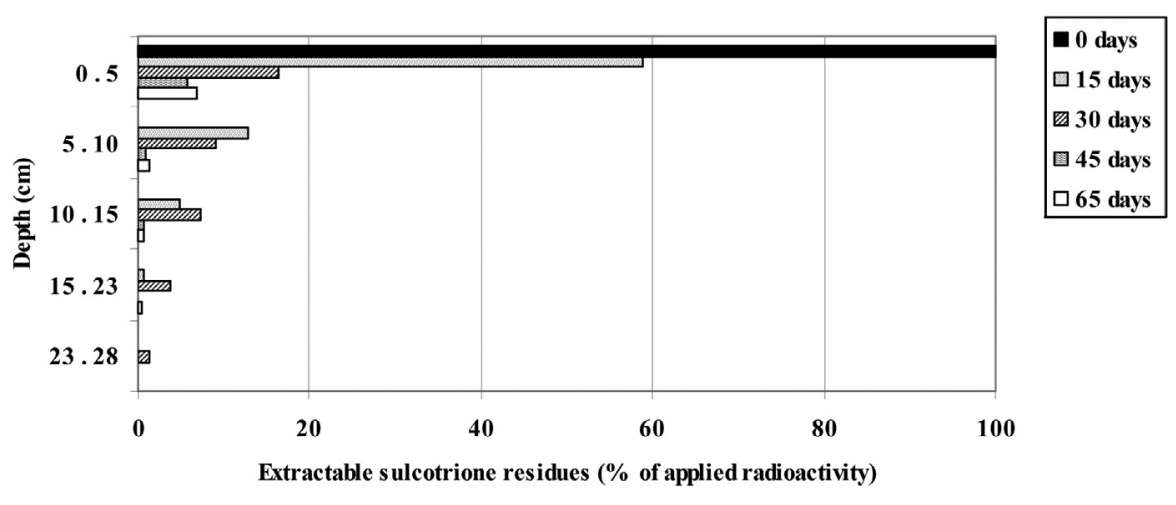

b.

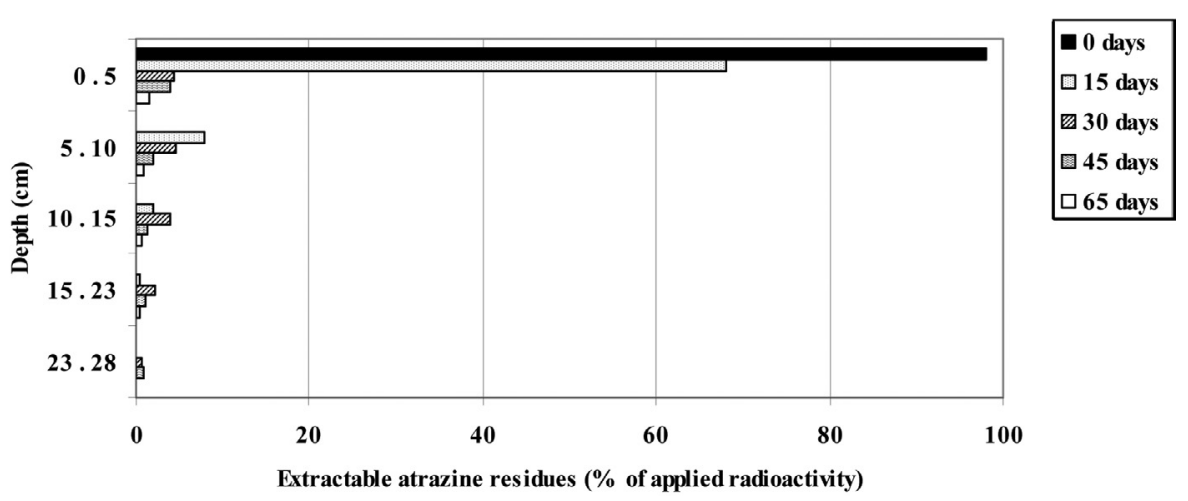

Figure 4. Distribution profile of extractable residues of sulcotrione (a) and atrazine (b) according to depth in soil. 
Table II. Mass balance of ${ }^{14} \mathrm{C}$-sulcotrione and ${ }^{14} \mathrm{C}$-atrazine residues during column transfer experiment as $\%$ of solvent extractable radioactivity. $\mathrm{nd}=$ not detected. $\mathrm{CMBA}=(2$-chloro-4(methylsulfonyl)benzoïc acid) $)$. DEA $=$ desethylatrazine; DIA $=$ deisopropylatrazine and $\mathrm{OH}-\mathrm{atz}=$ hydroxyatrazine.

\begin{tabular}{|c|c|c|c|c|c|c|c|c|}
\hline Times days & Depth cm & Sulcotrione & CMBA & Metabolite 2 & Atrazine & DEA & DIA & OH-atz \\
\hline \multirow[t]{5}{*}{0} & $0-5$ & 90 & 10 & 0 & 100 & nd & nd & nd \\
\hline & $5-10$ & nd & nd & nd & nd & nd & nd & nd \\
\hline & 10-15 & nd & nd & nd & nd & nd & nd & nd \\
\hline & $15-23$ & nd & nd & nd & nd & nd & nd & nd \\
\hline & $23-28$ & nd & nd & nd & nd & nd & nd & nd \\
\hline \multirow[t]{5}{*}{15} & $0-5$ & 18 & 70 & 12 & 85 & 15 & nd & nd \\
\hline & $5-10$ & 39 & 61 & 0 & 67 & 33 & nd & nd \\
\hline & 10-15 & 5 & 95 & 0 & 100 & nd & nd & nd \\
\hline & $15-23$ & nd & nd & nd & nd & nd & nd & nd \\
\hline & $23-28$ & nd & nd & nd & nd & nd & nd & nd \\
\hline \multirow[t]{5}{*}{30} & $0-5$ & 7 & 37 & 56 & 46 & 28 & 9 & 17 \\
\hline & $5-10$ & nd & 88 & 12 & 50 & 27 & 23 & nd \\
\hline & $10-15$ & nd & 100 & nd & 50 & 30 & 8 & 12 \\
\hline & $15-23$ & nd & 93 & 7 & 57 & 30 & 13 & nd \\
\hline & $23-28$ & nd & nd & nd & 11 & 64 & 25 & nd \\
\hline \multirow[t]{5}{*}{45} & $0-5$ & 11 & 53 & 36 & 53 & 23 & 15 & 9 \\
\hline & 5-10 & nd & nd & nd & 8 & 38 & 27 & 27 \\
\hline & $10-15$ & nd & nd & nd & 17 & 64 & nd & 19 \\
\hline & $15-23$ & nd & nd & nd & 5 & 63 & 16 & 16 \\
\hline & $23-28$ & nd & nd & nd & 15 & 37 & 20 & 28 \\
\hline \multirow[t]{5}{*}{60} & $0-5$ & 10 & 55 & 35 & 17 & 64 & 6 & 13 \\
\hline & 5-10 & nd & nd & nd & 15 & 30 & 22 & 33 \\
\hline & $10-15$ & nd & nd & nd & 18 & 34 & 16 & 32 \\
\hline & $15-23$ & nd & nd & nd & 33 & 43 & 15 & 9 \\
\hline & $23-28$ & nd & nd & nd & 29 & 19 & nd & 52 \\
\hline
\end{tabular}

the 3 metabolites (desethylatrazine, deisopropylatrazine and hydroxyatrazine) were present, the most significant of them being desethylatrazine. At days 45 and 65, we could just detect sulcotrione and its metabolites in the surface layer. The mother molecule represented around 10\%, and CMBA 55\%, of the extractable residues. For the atrazine, at the same times, we observed that the mother molecule and its metabolites could be detected throughout the profile. Atrazine content decreased from $53 \%$ to $17 \%$ in the top layer of the soil column, between day 45 and day 65 , simultaneously with desethylatrazine becoming the major element.

\subsubsection{Evolution of non-extractable residues in soils}

For both molecules, the major fraction of bound residues was formed during the first month of experiment and represented, respectively, for sulcotrione and atrazine, $10.4 \%$ and $12.1 \%$ (Tab. III). After 65 days, the non-extractable residues represented $12.5 \%$ of applied radioactivity for the sulcotrione and $15.2 \%$ for atrazine.

As a discussion, we can suggest that even if the experimental conditions, in terms of temperature, soil water content and rainfall allowed a favourable degradation activity of the two molecules, three important points can be drawn from this work.

Firstly, we were able to observe that the distribution of the pesticide residues in the leachates could be represented by three phases. After treatment, from 0 to 11 days, the climatic conditions, especially the lack of early rainfall (Fig. 1), did not permit an efficient leaching of products but contributed to the migration within the soil column. The first efficient rainfall, 11 days after treatment, induced a low-level leaching of the products. However, the presence of the products in the percolates (Fig. 3) leads us to suppose a displacement through the macroporosity and preferential flux (Johnson et al., 1994; Larsson and Jarvis, 1999; Novak et al., 2001). The following three rainfalls, from 19 to 33 days after treatment, exported more residues, especially due to the availability of products in the soil solution. The degradation of residues during the experiment could explain their decreasing availability for transfer with time, especially starting from 34 days after treatment.

Secondly, for the distribution profile of soil extractable residues, the presence of product in the whole soil profile was partly due to the interaction of three factors. The first of these was the low retention by soil constituents of both products. Koc values, obtained by batch equilibration (not shown here), for the sulcotrione and the atrazine were, respectively, $182( \pm 24)$ and $142( \pm 13)$ (Cherrier, 2003). Thus, the combination of the rainfall ( 6 draining periods) and the solubility of the products $\left(165 \mathrm{mg} \cdot \mathrm{L}^{-1}\right.$ for sulcotrione and $33 \mathrm{mg} \cdot \mathrm{L}^{-1}$ for atrazine) could explain the distribution of residue contents in the soil profile and in the percolate waters. Finally, the persistence of both products and their respective metabolites, according to Bear 
Table III. Distribution profile of non-extractable ${ }^{14} \mathrm{C}$ residues of sulcotrione and atrazine during the 65 days of the column experiment. Radioactivity measured through combustion (\% of applied radioactivity).

\begin{tabular}{|c|c|c|c|c|c|c|}
\hline \multirow[t]{2}{*}{ Molecule } & \multirow{2}{*}{$\begin{array}{l}\text { Depth } \\
\text { (cm) }\end{array}$} & \multicolumn{5}{|c|}{ Time after treatment (days) } \\
\hline & & $\mathbf{0}$ & 15 & 30 & 45 & 65 \\
\hline \multirow[t]{5}{*}{ Sulcotrione } & $00-05$ & nd & 3.5 & 4.8 & 5.2 & 4.5 \\
\hline & $05-10$ & nd & 1.5 & 2.4 & 2.0 & 3.3 \\
\hline & $10-15$ & nd & 0.8 & 1.6 & 1.6 & 2.4 \\
\hline & $15-23$ & nd & 0.4 & 1.1 & 1.0 & 1.7 \\
\hline & $23-28$ & nd & 0.2 & 0.5 & 0.5 & 0.6 \\
\hline \multicolumn{2}{|c|}{ Total non extractable residues $(\%)$} & nd & 6.4 & 10.4 & 10.3 & 12.5 \\
\hline \multirow[t]{5}{*}{ Atrazine } & $00-05$ & nd & 7.6 & 6.4 & 8.6 & 10.4 \\
\hline & $05-10$ & nd & 0.8 & 2.8 & 2.4 & 2.1 \\
\hline & $10-15$ & nd & 0.3 & 1.7 & 1.6 & 1.4 \\
\hline & $15-23$ & nd & 0.2 & 0.9 & 1.0 & 1.0 \\
\hline & $23-28$ & nd & 0.1 & 0.3 & 0.7 & 0.3 \\
\hline \multicolumn{2}{|c|}{ Total non extractable residues (\%) } & nd & 9.0 & 12.1 & 14.4 & 15.2 \\
\hline
\end{tabular}

(1996), Rouchaud et al. (1998b) and Cherrier et al. (2004) for sulcotrione, and Kaufman et al. (1970) and Houot et al. (2000) for the atrazine, explained the high contents of both products and their metabolites for 20 days after treatment and the decrease between days 20 and 65 after treatment (Tabs. I, II, Figs. 3, 4).

Lastly, the formation of non-extractable sulcotrione and atrazine residues in soil were low. These results could be explained by a fast degradation and mineralisation of the residues (Tab. II), due to the favourable edaphic conditions maintained by the natural and artificial rains (Fig. 1). The low formation of non-extractable residues could explain the high concentration of residues present in the percolates.

\section{CONCLUSION}

From this experiment, we concluded that sulcotrione seems to be a more mobile product than the atrazine. However, leaching risks for groundwater contamination would depend on the strength of subsoil sorption and degradation processes in relation to water transport times and solute dispersion. Much smaller leachate concentrations would be expected to impact groundwater than those found in this study, but the classification of the molecules would stay the same.

Acknowledgements: The authors are grateful to the French Ministry of Agriculture, Food, Fishing and Rural Businesses for their financial support of the research programme. The authors also wish to thank Bernard Colin and Stephan Colin for their technical help with the construction of the soil column devices. We also thank the two anonymous reviewers for their helpful comments.

\section{REFERENCES}

Assaf N.A., Turco R.F. (1994) Accelerated biodegradation of atrazine by a microbial consortium is possible in culture and soil, Biodegradation $5,29-35$.

Baer U. (1996) Comportement des pesticides dans les sols : Évaluation et simulation de la dissipation au champ, Thèse de Doctorat ès Sci- ences Agronomiques, Institut National Agronomie, Paris-Grignon, France.

Bailey G.W., White J.L., Rothberg T. (1968) Adsorption of organic herbicides by montmorillonite: role of $\mathrm{pH}$ and chemical character of adsorbate, Soil Sci. Soc. Am. Proc. 32, 222-234.

Barriuso E., Houot S. (1996) Rapid mineralization of the $s$-triazine ring of atrazine in soils in relation to soil management, Soil Biol. Biochem. $28,1341-1348$.

Beraud J.M., Compagnon J.M., Montury A. (1992) La sulcotrione (ICIA0051), base de nouvelles stratégies de désherbage complet du maïs, ANPP, Quinzième conférence du Columa, Journées internationales sur la lutte contre les mauvaises herbes, Versailles, pp. 457466.

Blanchoud H., Garban B., Ollivon D., Chevreuil M. (2002) Herbicides and nitrogen in precipitation: progression from west to east and contribution to the Marne river (France), Chemosphere 47, 1025-1031.

Calvet R., Terce M., Arvieu J.C. (1980) Mise au point bibliographique : adsorption des pesticides par les sols et leurs constituants. II. Les facteurs de l'adsorption, Ann. Agron. 31-2, 125-162.

Calvet R. (1988) Évaluation des coefficients d'adsorption et prédiction de la mobilité des pesticides dans les sols, Symposium INRA methodological aspects of the study of pesticide behaviour in soil, Versailles, pp. 119-125.

Cherrier R. (2003) Impact sur l'environnement de deux herbicides du maïs : la sulcotrione et l'atrazine - Influence du changement d'apports organiques, Thèse de Doctorat ès Sciences Agronomiques, Institut National Polytechnique de Lorraine, Nancy, France.

Cherrier R., Perrin-Ganier C., Schiavon M. (2004) Degradation of sulcotrione in a brown soil amended with various organic matters, Agronomie 24, 29-33.

Davoli E., Benfenati E., Bagnati R., Fanelli R. (1987) Analysis of atrazine in underground waters at part per trillion levels as an early warning method for contamination and for soil distribution studies, Chemosphere $16,1425-1430$.

Dousset S. (1994) Évaluation des potentialités de lessivage de la terbuthylazine et de l'atrazine dans trois sols de la région centre, Thèse de Doctorat ès Sciences Agronomiques, Institut National Polytechnique de Lorraine, Nancy, France.

Dousset S., Mouvet C., Schiavon M. (1994) Sorption of terbuthylazine and atrazine in relation to the physico-chemical properties of three soils, Chemosphere 28, 467-476. 
Fischer V.R., Siebers J. (1997) Rückstandsanalytik neuer planzenschutzmittelwirk-stoffe, Residues analysis of new pesticides, Nachrichtenbl Deut Pflanzenschutzd 49, 246-253.

Garmouna M., Teil M.J., Blanchard M., Chevreuil M. (1998) Spatial and temporal variations of herbicide (triazines and phenylureas) concentrations in the catchment basin of the Marne river (France), Sci. Total Environ. 224, 93-107.

Houot S., Topp E., Yassir A., Soulas G. (2000) Dependence of accelerated degradation of atrazine on soil $\mathrm{pH}$ in French and Canadian soils, Soil Biol. Biochem. 32, 615-625.

Johnson A.C., Haria A.H., Bhardwaj C.L., Volkner C., Batchelor C.H., Walker A. (1994) Water movement and isoproturon behaviour in a drained heavy clay soil: 2. Persistence and transport, J. Hydrol. 163 , 217-231.

Kaufman D.D., Kearney P.C. (1970) Microbial degradation of s-triazine herbicides, Residues Rev. 32, 235-265.

Larsson M.H., Jarvis N.J. (1999) Evaluation of a dual-porosity model to predict field-scale solute transport in a macro porous soil, J. Hydrol. $215,153-171$.

Moore M.T., Bennett E.R., Cooper C.M., Smith S., Shields F.D., Milam C.D., Farris J.L. (2001) Transport and fate of atrazine and lambdacyhalothrin in an agricultural drainage ditch in the Mississippi Delta, USA, Agr. Ecosyst. Environ. 87, 309-314.
Novak S.M., Portal J.M., Schiavon M. (2001) Effects of soil type upon metolachlor losses in subsurface drainage, Chemosphere 42, 235244.

Rouchaud J., Thirion A., Callens D., Bulcke R. (1996) Soil dissipation of the post-emergence herbicide sulcotrione in maize crops treated with organic fertilizers, Bull. Environ. Contam. Tox. 57, 398-405.

Rouchaud J., Neus O., Bulcke R., Cools K., Eelen H. (1998a) Sulcotrione soil metabolism in summer corn crops, Bull. Environ. Contam. Tox. 61, 669-676.

Rouchaud J., Neus O., Callens D., Bulcke R. (1998b) Sulcotrione soil persistence and mobility in summer maize and winter wheat crops, Weed Res. 38, 361-371.

Tan C.S., Drury C.F., Gaynor J.D., Welacky T.W., Reynolds W.D. (2002) Effect of tillage and water table control on evapotranspiration, surface runoff, tile drainage and soil water content under maize on a clay loam soil, Agr. Water Manage. 54, 173-188.

Wehtze G.R., Spalding R.F., Burnside O.C., Lowry S.R., Leavitt J.R (1983) Biological significance an fate of atrazine under aquifer conditions, Weed Sci. 31, 610-618.

Wilson S., Foy C. (1992) Influence of various soil properties on the adsorption and desorption of ICIA-0051 in five soils, Weed Technol. $6,583-586$. 